\title{
Prevention of human rabies: a challenge for the European Union and the European Economic Area
}

Céline M Gossner ${ }^{1}$, Alexandra Mailles ${ }^{2}$, Inma Aznar ${ }^{3}$, Elina Dimina ${ }^{4}$, Juan E Echevarría ${ }^{5,6}$, Siri Laura Feruglio ${ }^{7}$, Heidi Lange ${ }^{7}$, Francesco Paolo Maraglino ${ }^{8}$, Patrizia Parodi ${ }^{8}$, Jurijs Perevoscikovs ${ }^{4}$, Yves Van der Stede ${ }^{3}$, Tamás Bakonyi ${ }^{1}$

1. European Centre for Disease Prevention and Control (ECDC), Stockholm, Sweden

2. Santé publique France, Saint Maurice, France

3. European Food Safety Authority (EFSA), Parma, Italy

4. Centre for Disease Prevention and Control of Latvia, Riga, Latvia

5. Centro Nacional de Microbiología, Instituto de Salud Carlos III, Madrid, Spain

6. Centro de Investigación Biomédica en Red de Epidemiología y Salud Pública (CIBERESP), Madrid, Spain

7. Norwegian Institute of Public Health, Oslo, Norway

8. Ministry of Health, Rome, Italy

Correspondence: Celine M Gossner (Celine.Gossner@ecdc.europa.eu)

Gossner Céline M, Mailles Alexandra, Aznar Inma, Dimina Elina, Echevarría Juan E, Feruglio Siri Laura, Lange Heidi, Maraglino Francesco Paolo, Parodi Patrizia, Perevoscikovs Juriis, Van der Stede Yves, Bakonyi Tamás. Prevention of human rabies: a challenge for the European Union and the European Economic Area. Euro Surveill. 2020;25(38): pii=2000158. https://doi.org/10.2807/1560-7917.ES.2020.25.38.2000158

Rabies is enzootic in over one hundred countries worldwide. In the European Union/European Economic Area (EU/EEA), the vast majority of human rabies cases are travellers bitten by dogs in rabies-enzootic countries, mostly in Asia and Africa. Thus, EU/EEA travellers visiting rabies enzootic countries should be aware of the risk of being infected with the rabies virus when having physical contact with mammals. They should consider pre-exposure vaccination following criteria recommended by the World Health Organization and if unvaccinated, immediately seek medical attention in case of bites or scratches from mammals. As the majority of the EU/EEA countries are free from rabies in mammals, elimination of the disease (no enzootic circulation of the virus and low number of imported cases) has been achieved by 2020 . However, illegal import of potentially infected animals, mainly dogs, poses a risk to public health and might threaten the elimination goal. Additionally, newly recognised bat lyssaviruses represent a potential emerging threat as the rabies vaccine may not confer protective immunity. To support preparedness activities in EU/EEA countries, guidance for the assessment and the management of the public health risk related to rabies but also other lyssaviruses, should be developed.

\section{Background}

Rabies is a viral zoonosis that is enzootic in over one hundred countries around the world [1]. Rabies causes around 59,000 human deaths annually; $95 \%$ of those occur in Asia and Africa. There is a wide spectrum of clinical symptoms, ranging from furious to paralytic manifestations. Without prophylaxis, the fatality rate is near $100 \%$ [1].
Rabies lyssavirus (RABV) is present in the saliva of infected animals up to 10 days before onset of symptoms and is transmitted through contact between the saliva and wounds (e.g. following a bite or scratch) or mucosal surfaces (e.g. licking of mucosa) $[1,2]$. In Asia and Africa, human deaths result almost entirely from transmission of the virus by dogs; in the Americas, human deaths are mostly caused by bat-associated RABV [1]. Human-to-human transmission through donation of contaminated organs and tissues has occurred [3].

There are safe and effective human vaccines that are used both as pre- and post-exposure prophylaxis. The World Health Organization (WHO) recommends preexposure prophylaxis (PrEP) for (i) people who are at high risk of exposure to RABV and other lyssaviruses because of their profession or their engagement in particular activities (e.g. animal healthcare workers; people doing caving) and, (ii) people travelling to remote areas where timely access to adequate postexposure prophylaxis (PEP) cannot be guaranteed or if the individual is at high risk of contact with wild animals, particularly bats [1]. The type of contact with the suspected lyssavirus-shedding animal determines the indicated PEP procedures which consist of thorough washing and flushing of the wound, prompt initiation of a post-exposure vaccination scheme, and, if indicated, administration of immunoglobulins. With a prompt and proper PEP, exposed patients have a survival rate close to $100 \%[1]$.

This perspective article on human rabies in the European Union/European Economic Area (EU/EEA) aims to (i) provide an overview of the current epidemiological 
TABLE 1

Characteristics of the travel-related rabies cases reported in Europe, 2006-2019 ( $\mathrm{n}=18$ )

\begin{tabular}{|c|c|c|c|c|c|c|c|c|}
\hline $\begin{array}{l}\text { Year of } \\
\text { symptom } \\
\text { onset }\end{array}$ & $\begin{array}{l}\text { Number } \\
\text { of human } \\
\text { cases }\end{array}$ & $\begin{array}{l}\text { Country of } \\
\text { residence }\end{array}$ & $\begin{array}{l}\text { Country of } \\
\text { infection }\end{array}$ & $\begin{array}{l}\text { Regiona of } \\
\text { infection }\end{array}$ & $\begin{array}{l}\text { Prompt post- } \\
\text { exposure } \\
\text { prophylaxis }\end{array}$ & $\begin{array}{l}\text { Animal } \\
\text { exposure }\end{array}$ & $\begin{array}{c}\text { Estimated } \\
\text { incubation } \\
\text { period }\end{array}$ & References \\
\hline 2006 & 1 & Lithuania & India & Southern Asia & No & Dog & Unknown & [4] \\
\hline \multirow{2}{*}{2007} & \multirow{2}{*}{2} & Germany & Morocco & Northern Africa & No & Dog & ca 6 weeks & {$[4,41]$} \\
\hline & & Finland & Philippines & South-eastern Asia & No & Dog & $<2$ months & {$[4,42]$} \\
\hline 2008 & 1 & $\begin{array}{c}\text { United } \\
\text { Kingdom }\end{array}$ & South Africa & $\begin{array}{c}\text { Sub-Saharan } \\
\text { Africa }\end{array}$ & No & Dog & 24 months & {$[4,43]$} \\
\hline \multirow{2}{*}{2011} & \multirow{2}{*}{2} & Portugal & Guinea Bissau & Western Africa & No & Dog & s3 months & {$[4,44]$} \\
\hline & & Italy & India & Southern Asia & $Y_{e s}^{b}$ & Dog & «1 month & {$[24]$} \\
\hline 2012 & 1 & $\begin{array}{l}\text { United } \\
\text { Kingdom }\end{array}$ & India & Southern Asia & No & Dog & <3 months & {$[4,45]$} \\
\hline 2013 & 1 & $\begin{array}{l}\text { The } \\
\text { Netherlands }\end{array}$ & Haiti & Caribbean & No & Dog & <2 months & {$[4,46]$} \\
\hline \multirow{3}{*}{2014} & \multirow{3}{*}{3} & $\begin{array}{c}\text { The } \\
\text { Netherlands }\end{array}$ & India & Southern Asia & Yes $^{b}$ & Dog & ca 8 weeks & {$[4,47]$} \\
\hline & & France & Mali & Western Africa & No & Unknown & 1 to 6 months & {$[4,48]$} \\
\hline & & Spain & Morocco & Northern Africa & No & Dog & 6 months & {$[4,49]$} \\
\hline 2016 & 1 & France & Bangladesh & Southern Asia & No & Dog & Unknown & {$[4]$} \\
\hline 2017 & 1 & France & Sri Lanka & Southern Asia & No & Dog & $<2$ months & {$[4,50]$} \\
\hline 2018 & 1 & $\begin{array}{c}\text { United } \\
\text { Kingdom }\end{array}$ & Morocco & Northern Africa & No & Cat & 2 months & {$[4,51]$} \\
\hline \multirow{4}{*}{2019} & \multirow{4}{*}{4} & Norway & Philippines & South-eastern Asia & No & Dog & <2 months & {$[4,52]$} \\
\hline & & Latvia & India & Southern Asia & No & Dog & 18 months & {$[4,52]$} \\
\hline & & Spain & Morocco & Northern Africa & No & Cat & 4 months & {$[4,52]$} \\
\hline & & Italy & Tanzania & Eastern Africa & Yes $^{b}$ & Dog & 1 month & {$[4,52]$} \\
\hline
\end{tabular}

a Based on the United Nations Statistics Division [45].

${ }^{b}$ Vaccination only, in the country of exposure.

Countries that reported cases: Finland $(n=1)$, France $(n=3)$, Germany $(n=1)$, Italy $(n=2)$, Latvia $(n=1)$, Lithuania $(n=1)$, the Netherlands $(n=2)$, Norway $(n=1)$, Portugal $(n=1)$, Spain $(n=2)$ and the United Kingdom $(n=3)$.

situation in humans and animals in the EU/EEA; (ii) highlight the risk among travellers globally and within the region (iii) present prevention opportunities and challenges for countries; and (iv) suggest actions for surveillance and preparedness. While the main focus is on rabies, we briefly address the risk related to other lyssaviruses.

\section{Human rabies cases}

Based on data collected by the European Centre for Disease Prevention and Control and a non-systematic review, we concluded that there have been, 18 travelrelated cases of rabies in the EU/EEA between 2006 and 2019; ranging from none (e.g. in 2015) to four (in 2019) cases per year (Table 1). Detailed information on the data search is provided in the supplementary material. The mean age was 44 (interquartile range: 38-55). The female-to-male ratio was 0.6:1. All cases were infected in rabies-enzootic countries. The mean incubation period was around 5 months. All cases died of their infection.

Seven of the travel-related cases were infected in southern Asia (i.e. India, Bangladesh, Sri Lanka), four in northern Africa (i.e. Morocco), two in western Africa (i.e. Mali, Guinea Bissau), two in south-eastern Asia (i.e. Philippines), one in eastern Africa (i.e. Tanzania), one in Sub-Saharan Africa (i.e. South Africa), and one in the Caribbean (i.e. Haiti) . Sixteen cases were infected through dog bites and two cases through cat bites. To our knowledge, none of the cases had received PrEP. Fifteen cases did not receive prompt PEP after exposure and three cases received incomplete PEP in the country of infection (i.e. no immunoglobulins were provided).

In addition, during the studied period, France and Romania reported locally acquired (non travel-related) rabies cases. The case in France resided in the overseas department of French Guiana where he got infected in 2008 [4]. In Romania, there was on average one case per year until 2012, the year of the last locally acquired infection in the country [4].

\section{Animal rabies cases}

\section{Rabies in terrestrial mammals}

The most important reservoir host of RABV in Europe is the red fox (Vulpes vulpes) [5]. Rabies in dogs was progressively eliminated at the turn of the 2oth century in most EU/EEA countries. As this large achievement in the domestic population took place, an epidemic in red foxes as a result of a spill over event from domestic animals to red foxes commenced in the 1940s [6]. 
Description of rabies national veterinary programmes in 12 European Union countries and number of animal cases, 2019 $[8]$

\begin{tabular}{|c|c|c|c|c|}
\hline Country & Doses of vaccines & Vaccine type & Vaccine coverage area $\left(\mathrm{km}^{2}\right)$ & $\begin{array}{l}\text { Number of } \\
\text { animal cases in } \\
2019\end{array}$ \\
\hline Bulgaria & $2,874,950$ & Lysvulpen (SAD, Bern, Switzerland) & 23 regions: $57,019 \mathrm{~km}^{2}$ & 0 \\
\hline Estonia & 280,600 & $\begin{array}{c}\text { Rabitec (strain SPBN GASGAS, IDT } \\
\text { Biologika GmbH, Dessau-Rosslau, } \\
\text { Germany) }\end{array}$ & Border facing Russia: $6,100 \mathrm{~km}^{2}$ & 0 \\
\hline Greece & $2,980,200$ & Lysvulpen & $\begin{array}{l}\text { Parts of the country: } \\
59,604 \mathrm{~km}^{2}\end{array}$ & 0 \\
\hline Finland & $\begin{array}{l}\text { Finland: } 180,000 \\
\text { Russia: } 30,970\end{array}$ & Rabitec & South-eastern border facing Russia: $10,000 \mathrm{~km}^{2}$ & 0 \\
\hline Croatia & $2,665,850$ & Lysvulpen & $\begin{array}{l}\text { Whole continental area without Adriatic islands: } \\
\qquad 53,317 \mathrm{~km}^{2}\end{array}$ & 0 \\
\hline Hungary & $\begin{array}{l}\text { Hungary: } 1,680,000 \\
\text { Ukraine: } 510,000\end{array}$ & $\begin{array}{l}\text { Rabigen SAG2 oral suspension } \\
\text { (VIRBAC S.A.,Carros, France) }\end{array}$ & $\begin{array}{l}\text { Hungary: } 9 \text { regions bordering Romania, Serbia, } \\
\text { Croatia, Slovakia and Ukraine: } \\
\qquad 41,970 \mathrm{~km}^{2} \\
\text { Ukraine: } 10,200 \mathrm{~km}^{2}\end{array}$ & 0 \\
\hline Lithuania & $\begin{array}{l}\text { Lithuania: } \\
\text { 1,010,000 } \\
\text { Belarus: } 1,650,000\end{array}$ & Lysvulpen & $\begin{array}{l}\text { Border facing Russia and Belarus. } \\
\text { In Lithuania: } 20,400 \mathrm{~km}^{2} \\
\text { In Belarus: } 33,000 \mathrm{~km}^{2}\end{array}$ & 0 \\
\hline Latvia & $\begin{array}{l}\text { Latvia: } 962,250 \\
\text { Belarus:542,500 }\end{array}$ & $\begin{array}{l}\text { In Latvia Lysvulpen (Bioveta A.S., } \\
\text { Ivanovice na Hané,Czech Republic); } \\
\text { In Belarus Rabivac-0/333 (Pokrov } \\
\text { biological plant, Volginsky, Russia) }\end{array}$ & $\begin{array}{l}\text { Border facing Russia and Belarus. } \\
\text { In Latvia: } 19,245 \mathrm{~km}^{2} \\
\text { In Belarus: } 10,850 \mathrm{~km}^{2}\end{array}$ & 0 \\
\hline Poland & $\begin{array}{l}\text { Poland: } 6,007,728 \\
\text { Belarus: } 604,000 \\
\text { Ukraine: } 1,922,500\end{array}$ & $\begin{array}{l}\text { Lysvulpen; Rabigen SAG2 oral } \\
\text { suspension; Rabitec }\end{array}$ & $\begin{array}{c}\text { Poland: } 8 \text { regions } 100,564 \mathrm{~km}^{2} \\
\text { Belarus: } 12,080 \mathrm{~km}^{2} \\
\text { Ukraine: buffer zone with Poland } 50 \mathrm{~km} \text {, } \\
38,450 \mathrm{~km}^{2}\end{array}$ & 1 (red fox) \\
\hline Romania & $\begin{array}{c}\text { Romania: } \\
\text { 10,819,550 } \\
\text { Ukraine: } 1,134,500 \\
\text { Moldova: } 3,720\end{array}$ & $\begin{array}{c}\text { Romania: Lysvulpen } \\
\text { Ukraine: Brovarabies V-RG } \\
\text { (Ukrvetprompostach, Brovary, } \\
\text { Ukraine) } \\
\text { Moldova: Lysvulpen }\end{array}$ & $\begin{array}{l}\text { Romania: whole country, } 213,375 \mathrm{~km}^{2} \\
\text { Ukraine: } 100 \mathrm{~km} \text { from border: } 22,500 \mathrm{~km}^{2} \\
\text { Moldova: } 50 \mathrm{~km} \text { from border, } 14,560 \mathrm{~km}^{2}\end{array}$ & $\begin{array}{l}4 \text { (2 red foxes, } \\
1 \text { wild boar and } \\
1 \text { cow) }\end{array}$ \\
\hline Slovakia & 632,800 & Lysvulpen & $\begin{array}{l}\text { Borders facing Hungary, Ukraine and Poland: } \\
\qquad 12,708 \mathrm{~km}^{2}\end{array}$ & 0 \\
\hline Slovenia & 760,000 & Rabitec & $\begin{array}{l}\text { Borders facing Croatia and Hungary: } \\
\qquad 7,800 \mathrm{~km}^{2}\end{array}$ & 0 \\
\hline
\end{tabular}

Attempts to interrupt the virus spread by reducing the red fox population below a threshold (so that intraspecific transmission was halted) failed because the necessary threshold was not reached [7].

Since the end of 1980 s and following a number of successful vaccine field trials, a large oral rabies vaccination campaign in red foxes commenced in the EU. This campaign has been politically supported and cofinanced by the EU and EU countries and covers not only these countries but also some of the EU's neighbouring countries along its eastern and south-eastern borders (Table 2) $[8,9]$. By the time this campaign was launched, the EEA countries Iceland and mainland Norway were rabies-free among red foxes. Vaccination in Liechtenstein was not co-financed but the country participated to a joint vaccination campaign with Switzerland and obtained the rabies free status in 1986 [10].

Oral rabies vaccination campaigns have been remarkably successful in controlling the infection in red foxes. In the EU/EEA in 2019, only a small number of animal cases occurred, all in eastern EU countries, and 
TABLE 3

Number of animal rabies cases reported from EU/EEA countries in foxes, raccoon dogs, farmed animals, dogs and cats, $2010-2019(\mathrm{n}=3,323)$

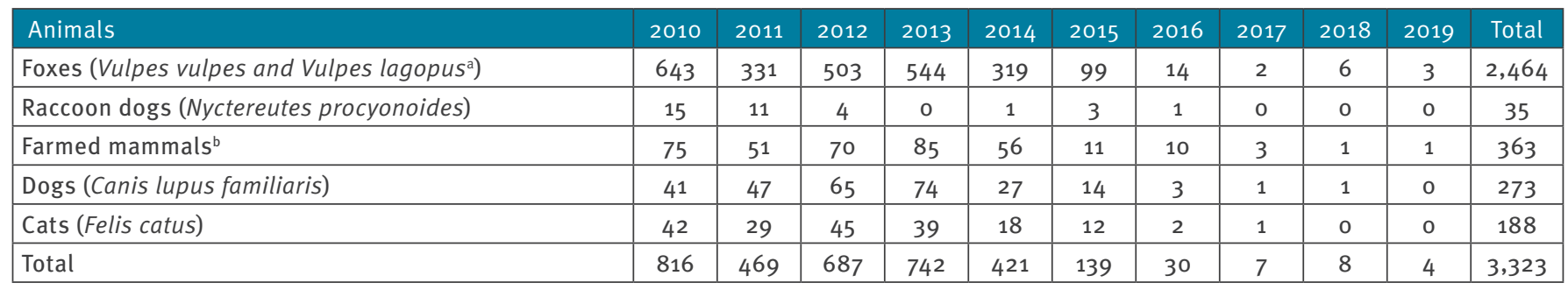

EU/EEA: European Union/European Economic Area.

a Norway (Svalbard and Jan Mayen) reported five, two and four cases in Arctic foxes (Vulpes lagopus), in 2011, 2012 and 2018, respectively; all other cases were red foxes.

${ }^{b}$ Farmed mammals: sheep, goats, pigs, solipeds, farmed pet animals other than dogs and cats.

Source: Data for 2010 to 2018 were reported to the European Food Safety Authority using the Data Collection Framework; data for 2019 were reported via the Animal Disease Notification System of the European Commission. Data downloaded on 17 December 2019.

Note: Other species found infected in small numbers are not included in the table (among others, badgers, deer, marten, rodents, jackals, lynx, bears, hares, hedgehogs, minks, wolverine, wild boar, squirrels, ferrets, otter, polecat, etc.).

achieving elimination of rabies in mammals (no enzootic circulation of the virus and low number of imported cases) has been achieved by 2020 [11]. Between 2010 and 2019, the highest proportion of animal cases were found in red foxes (Table 3). A gradual decrease in the total number of cases among this species was observed over the years. Since 2017, the overall yearly number of rabies cases has been below 10 and only four EU countries have reported cases: Lithuania, Romania, Poland and Hungary [11]. In addition, Norway reported the detection of rabies cases among Arctic foxes on the islands of Svalbard and Jan Mayen.

In 2019, five animal rabies cases were reported, four in Romania (two in red foxes, one in a cow and a wild boar, respectively) and one in Poland (red fox) [12]. The case in Poland was found in proximity to the border with Belarus and Ukraine. In Romania, one of the red foxes was found close to the border with Hungary and Ukraine, and the other animal cases near the border with Moldova. In Ukraine in 2019, 260 cases of domestic rabies cases were reported, 101 in dogs and 138 in cats, and 262 cases were reported in wild animals, 232 of them were red foxes. No data were reported for Moldova or Belarus.

\section{Bat rabies}

Rabies virus has not been found in native bats of Europe but has been found in other continents and is a major source of human infections in the Americas $[13,14]$.

\section{Infections with other lyssaviruses}

Lyssaviruses other than RABV have been detected in the EU/EEA and EU neighbouring countries. The European bat lyssavirus type 1 and 2 (EBLV-1 and EBLV2 , respectively) have bats as their main host and have been linked, in rare occasions, to infections in other animals and humans. In 2018, a total of 45 EBLV-1 and EBLV-2 bat cases were detected in France, Germany, Hungary, the Netherlands, Poland, Spain and the
United Kingdom (UK) [15]. EBLV-1 has been detected in sheep in Denmark [16], in a stone marten in Germany [17], as well as in cats in France [18].

Four human deaths of EBLV-1 and EBLV-2 have been recognised so far in Europe: Ukraine (1977), Russia (1985), Finland (1985) and the UK (2002) [19].

To date, four other bat lyssavirus species were detected in the EU/EEA and their neighbouring countries, the Bokeloh bat lyssavirus, the Lleida bat lyssavirus, the West Caucasian bat lyssavirus and the Kotalahti bat lyssavirus (tentative species). No human cases were so far associated to these four other bat lyssaviruses [20]. In 2020, for the first time, a cat, who had a suspected exposure to bats, was tested positive for the West Caucasian bat lyssavirus in Italy [21].

In addition, one fatal human case of Duvenhage lyssavirus infection was diagnosed in the Netherlands in 2007 [22]. The person was bitten by a bat while she was in Tsavo West National Park, Kenya.

\section{Risk related to rabies}

Risk for travellers visiting rabies enzootic areas For the majority of EU/EEA countries, rabies has become a disease of travellers being bitten or scratched by dogs or cats in countries with uncontrolled dog- and cat-derived rabies. Four travel-related human cases of rabies were reported in the EU/EEA in 2019. This is the highest number of cases reported in a year but only represents a slight increase compared to 2014 when there were three cases. This slight increase is not considered to reflect a change in the risk for travellers as there is no indication of a recent increase of the incidence of rabies in the reported countries of infection. However, we believe that the four cases reported in 2019 may highlight a lack of awareness among EU/EEA travellers, as it has been described by Marano et al. [23]. 
Based on reported data there are two groups of individuals potentially at higher risk of being exposed and/ or contracting the disease: first, people who handle puppies and kittens and do not consider it a risk of exposure; second, people who are bitten/scratched by dogs or cats but do not seek medical attention.

In this regard, travel clinics and public health authorities in the EU/EEA may reinforce their prevention campaigns, advising travellers visiting countries with moderate and high risk of rabies (i) to be aware of the possibility of acquiring RABV infection when having physical contact with mammals, (ii) to get PrEP vaccination following criteria recommended by WHO and (iii) to immediately seek medical attention in case of bites or scratches from mammals. Dedicated communication campaigns should be developed for different groups of travellers and levels of awareness and the use of social media to reach them should be explored. In addition, travellers should be reminded to follow veterinary rules and regulations when travelling with pets. Furthermore EU/EEA citizens should only acquire pets through authorised channels.

\section{Pre- and post-exposure vaccination}

To our knowledge, none of the travel-related cases reported in the EU/EEA had received PrEP and very few received prompt, but incomplete PEP after exposure. Several case reports highlighted that injured travellers who sought medical attention in countries considered at medium and high risk for rabies exposure did not receive adequate PEP, either because vaccines and/ or immunoglobulins were unavailable or they were improperly administered [24-26]. Three of the travelrelated cases reported in the EU/EEA had sought medical attention after exposure and received PEP in the country of exposure (i.e. India and Tanzania) but the scheme was incomplete and all developed rabies. Travellers from the EU/EEA receiving PEP in endemic countries should seek medical attention when returning to their country in order to check the adequacy of the treatment received.

Several studies have looked into the causes of nonvaccination of travellers. The cost of the vaccine, the lack of knowledge about the risk among travellers and healthcare providers and, the relatively long time to complete the vaccine course were the most frequent causes of being non-vaccinated [27]. Since 2018, the WHO recommends a vaccination schedule of 1 week, with only two doses, hence reducing the planning complexity and cost for travellers [28]. While the vaccine might still be considered expensive (up to EUR 100 per dose), the resulting immunity is long-lasting and the investment should be considered attractive for travellers who travel repetitively to rabies-enzootic areas [28]. In addition, PEP for vaccinated patients has been simplified: two vaccine doses over 3 days and no immunoglobulins are needed, an important point that healthcare providers in the EU/EEA should take into account considering that several EU/EEA countries have recently experienced temporary but occasionally recurrent shortages in vaccines and/or human immunoglobulins [29-31]. Although these shortages were resolved, national authorities had to temporarily restrict the use of the vaccine for PEP $[32,33]$. The provision of falsified vaccines has been highlighted as a public health issue as recently demonstrated outside the EU/EEA, e.g. in the Philippines and in China [34].

In 2018, the WHO and its partners have in their 'zeroby-30' initiative set the goal to end human deaths from classical rabies by 2030 [35]. Through a One Health approach, the initiative focuses on carnivores' vaccination, control of stray dogs, access to PEP for exposed people and rabies education and awareness. However, for the initiative to be successful, there is an increasing need of affordable vaccines and immunoglobulins in countries considered at medium and high risk of RABV infection.

\section{Risk related to substances of human origin}

Rabies virus is not found in blood; there is nonetheless a risk related to the transplantation of organs and tissues from infected donors in whom rabies was not diagnosed. Such events are fortunately very rare thanks to donor's selection criteria implemented in most countries [36,37].

\section{Risk related to domestic carnivores}

A considerable risk of human rabies still exists within the EU/EEA with the illegal importation of domestic carnivores (mainly dogs) from non-rabies free countries, especially northern Africa [38,39]. For instance, France identified in February 2020 a rabid dog illegally imported from Morocco [40].

\section{Risk related to other lyssaviruses}

Bat lyssaviruses represent a potential emerging threat in the EU/EEA. Few fatal human cases of EBLV-1 and EBLV-2 have occurred in the EU, but the most concerning is the potential emergence of newly recognised bat lyssaviruses for which the pathogenicity for humans is unknown and for which the rabies vaccine may not confer protective immunity [20]. The recent detection of the West Caucasian bat lyssavirus in a cat with clinical symptoms in Italy indicates that emerging lyssaviruses may potentially infect other terrestrial mammal species including humans. Although this remains an isolated event, there is a need to promote further research including for the development of rabies vaccines covering a wide range of lyssaviruses.

Even though bats may be present on the roof or attic of buildings or homes in the EU/EEA, interactions between bats and humans are expected to be rare. As a general precaution, it is recommended to avoid contacts with bats and their excreta and seek medical attention in case of accidental exposure. 


\section{Conclusion}

As rabies among mammals is nearly eliminated from the EU/EEA, the risk for EU/EEA citizens is mostly related to travel to enzootic areas. Travellers should be aware of this risk, consider pre-exposure vaccination following recommended criteria by the WHO and those unvaccinated, should immediately seek medical attention in case of bites or scratches from mammals. Dedicated communication campaigns should be developed for travellers in risk groups. Even though exposures are generally limited, bat lyssavirus infection represents a potential emerging threat in the EU/EEA.

To support preparedness activities in EU/EEA countries, guidance for the assessment and the management of the public health risk related to rabies but also other lyssaviruses should be developed. Maintaining surveillance of animal and human rabies in countries or regions free from terrestrial rabies is essential to be able to early detect and efficiently manage any re-occurrence or re-emergence of the disease. Continuation of oral vaccination campaigns at the EU/EEA bordering regions with regular resurgence of rabies would reduce the risk of rabies re-emergence. This is particularly important at the eastern borders of the EU, as rabies is still enzootic in neighbouring countries.

\section{Disclaimer}

Yves Van der Stede and Inma Aznar are currently employed with the European Food Safety Authority (EFSA) in the ALPHA Unit that provides scientific and administrative support to EFSA's scientific activities in the area of Animal Health and Welfare. The positions and opinions presented in this article are those of the authors alone and are not intended to represent the views or scientific work of EFSA.

\section{Acknowledgements}

The authors thank Dragoslav Domanovic from ECDC for his contribution regarding donations of substance of human origin. We also thank Pedro Rosado Martin from the European Commission for his thorough review of the manuscript.

\section{Conflict of interest}

None declared.

\section{Authors' contributions}

CMG prepared the outline that was reviewed by all authors. CMG drafted the manuscript with the support of $A M$ and IA. AM, ED, JEE, SLF, HL, FPM, PP, JP provided detailed information about human infections in their respective countries. IA, YVdS and JEE provided input on animal infections in the EU/ EEA. TB and JEE provided input on the microbiological aspects of the infection. All the authors critically revised the manuscript to improve its quality and comprehensiveness. All the authors approved the final version.

\section{References}

1. World Health Organization (WHO). WHO expert consultation on rabies: third report. Geneva: WHO; 2018. Available from https://apps.who.int/iris/handle/10665/272364

2. Fekadu M, Shaddock JH, Baer GM. Excretion of rabies virus in the saliva of dogs. J Infect Dis. 1982;145(5):715-9. https://doi. org/10.1093/infdis/145.2.715 PMID: 7077094

3. Vora NM, Orciari LA, Niezgoda M, Selvaggi G, Stosor V, Lyon GM 3rd, et al. Clinical management and humoral immune responses to rabies post-exposure prophylaxis among three patients who received solid organs from a donor with rabies. Transpl Infect Dis. 2015;17(3):389-95. https://doi.org/10.1111/ tid.12393 PMID: 25851103

4. European Centre for Disease Prevention and Control (ECDC). The European Surveillance System (TESSy) [restricted access]. Stockholm: ECDC. [Accessed: 8 Jul 2020]. Available from: https://ecdc.europa.eu/en/publications-data/ european-surveillance-system-tessy

5. Cliquet F, Aubert M. Elimination of terrestrial rabies in Western European countries. Dev Biol (Basel). 2004;119:185-204. PMID: 15747421

6. Finnegan CJ, Brookes SM, Johnson N, Smith J, Mansfield $\mathrm{KL}$, Keene VL, et al. Rabies in North America and Europe. J R Soc Med. 2002;95(1):9-13. https://doi. org/10.1177/014107680209500104 PMID: 11773344

7. European Commission (EC). Health and consumer protection directorate general. The oral vaccination of foxes against rabies. Report of the Scientific Committee on Animal Health and Animal Welfare. Adopted on 23 October 2002. Brussels EC; 2002. Available from: https://ec.europa.eu/food/sites/ food/files/safety/docs/sci-com_scah_out8o en.pdf

8. European Commission (EC). National Veterinary Programmes. Brussels: EC. [Accessed: 8 Jul 2020]. Available from: https://ec.europa.eu/food/funding/animal-health/ national-veterinary-programmes_en

9. World Organisation for Animal Health (OIA). Ninth meeting of the standing group of experts on lumpy skin disease (SGE LSD9), 16-17 October 2019, Athens/Greece - additional session on rabies surveillance. Paris: OIE. [Accessed: 8 Jul 2020]. Available from: https://web.oie.int/RR-Europe/eng/Regprog/ en GF TADS\%20-\%20Standing\%20Group\%20LSD.htm\#LSD

10. King AA, Fooks AR, Aubert M, Wandeler Al. Historical Perspective of Rabies in Europe and the Mediterranean Basin. Paris: OIE; 2004. p140-142. Available from: https:// foxrabiesblueprint.org/IMG/pdf/pdf_106_king_et_al_2004.pdf

11. Robardet E, Bosnjak D, Englund L, Demetriou P, Martín PR, Cliquet F. Zero Endemic Cases of Wildlife Rabies (Classical Rabies Virus, RABV) in the European Union by 2020: An Achievable Goal. Trop Med Infect Dis. 2019;4(4):124. https:// doi.org/10.3390/tropicalmed4040124 PMID: 31575054

12. World Health Organization (WHO). Rabies Bulletin Europe - Rabies Information System - queries. Geneva: WHO. [Accessed: 8 Jul 2020]. Available from: https://rbe.fli.de/ site-page/queries

13. Escobar LE, Peterson AT, Favi M, Yung V, Medina-Vogel G. Bat-borne rabies in Latin America. Rev Inst Med Trop São Paulo. 2015:57(1):63-72. https://doi.org/10.1590/So03646652015000100009 PMID: 25651328

14. Centers for Disease Control and Prevention (CDC). Bats Lead in U.S. Rabies Risk. Atlanta: CDC. [Accessed: 21 Sep 2020]. Available from: https://www.cdc.gov/media/releases/2019/ po611-bats-rabies.html\#: : :text=Bats\%20are $\% 20$ responsible $\% 2$ ofor\%2oroughly,for $\% 20$ Disease $\% 20$ Control\%20 and $\% 20$ Prevention

15. European Food Safety Authority and European Centre for Disease Prevention and Control. The European Union One Health 2018 Zoonoses Report. EFSA Journal. 2019;17(12):5926, 276 pp. http://dx.doi.org/ https://doi.org/10.2903/j. efsa.2019.5926

16. Tjørnehøj K, Fooks AR, Agerholm JS, Rønsholt L. Natural and experimental infection of sheep with European bat lyssavirus type-1 of Danish bat origin. J Comp Pathol. 2006;134(2-3):190201. https://doi.org/10.1016/j.jcpa.2005.10.005 PMID: 16545840

17. Müller T, Cox J, Peter W, Schäfer R, Johnson N, McElhinney LM, et al. Spill-over of European bat lyssavirus type 1 into a stone marten (Martes foina) in Germany. IVet Med B Infect Dis Vet Public Health. 2004;51(2):49-54. https://doi.org/10.1111/ j.1439-0450.2003.00725.X PMID: 15030600

18. Dacheux L, Larrous F, Mailles A, Boisseleau D, Delmas O, Biron C, et al. European bat Lyssavirus transmission among cats, Europe. Emerg Infect Dis. 2009;15(2):280-4. https://doi. org/10.3201/eid1502.080637 PMID: 19193273

19. Fooks AR, Brookes SM, Johnson N, McElhinney LM, Hutson AM. European bat lyssaviruses: an emerging zoonosis. Epidemiol 
Infect. 2003;131(3):1029-39. https://doi.org/10.1017/ So950268803001481 PMID: 14959767

20. Echevarría JE, Banyard AC, McElhinney LM, Fooks AR. Current Rabies Vaccines Do Not Confer Protective Immunity against Divergent Lyssaviruses Circulating in Europe. Viruses. 2019;11(10):E892. https://doi.org/10.3390/v11100892 PMID: 31554170

21. Istituto Zooprofilattico Sperimentale delle Venezie (IZSVe). Caso di Lyssavirus in un gatto nel comune di Arezzo. [A case of Lyssavirus in a cat in the commune of Arezzo]. Legnaro: IZSVe; 29 Jun 2020. Italian. Available from: https://www.izsvenezie.it/ caso-lyssavirus-gatto-comune-arezzo/

22. van Thiel P-PAM, de Bie RMA, Eftimov F, Tepaske R, Zaaijer HL, van Doornum GIJ, et al. Fatal human rabies due to Duvenhage virus from a bat in Kenya: failure of treatment with coma-induction, ketamine, and antiviral drugs. PLoS Negl Trop Dis. 2009;3(7):e428. https://doi.org/10.1371/journal. pntd.0000428 PMID: 19636367

23. Marano C, Moodley M, Melander E, De Moerlooze L, Nothdurft HD. Perceptions of rabies risk: a survey of travellers and travel clinics from Canada, Germany, Sweden and the UK. J Travel Med. 2019;26(Supplement_1):S3-S9. http://dx.doi.org/ https:// doi.org/10.1093/jtm/tayo62 PMID: 30476212

24. De Benedictis P, Perboni G, Gentili C, Gaetti L, Zaffanella $\mathrm{F}$, Mutinelli F, et al. Fatal case of human rabies imported to Italy from India highlights the importance of adequate post-exposure prophylaxis, October 2011. Euro Surveill. 2012;17(19):20168. PMID: 22607965

25. Gautret P, Angelo KM, Asgeirsson H, Lalloo DG, Shaw M, Schwartz E, et al. Rabies post-exposure prophylaxis started during or after travel: A GeoSentinel analysis. PLoS Negl Trop Dis. 2018;12(11):e0006951. https://doi.org/10.1371/journal. pntd.0006951 PMID: 30422981

26. Johnson N, Freuling C, Horton D, Muller T, Fooks AR. Imported rabies, European Union and Switzerland, 2001-2010. Emerg Infect Dis. 2011;17(4):753-4. https://doi.org/10.3201/ eid1706.101154 PMID: 21470483

27. Gautret P, Parola P. Rabies vaccination for international travelers. Vaccine. 2012;30(2):126-33. https://doi. org/10.1016/j.vaccine.2011.11.007 PMID: 22085557

28. World Health Organization (WHO). Rabies vaccines: WHO position paper - April 2018. Geneva: WHO; 20 Apr 2018 Available from: https://www.who.int/rabies/resources/ who_wer9316/en/

29. Hermans F. Nederlandse reiziger moet zonder inenting tegen hondsdolheid naar de tropen. [Dutch travellers must go to the tropics without vaccination against rabies]. Nijmegen: de Gelderlander; 21 Jun 2018. Dutch. Available from: https://www. gelderlander.nl/nijmegen/nederlandse-reiziger-moet-zonderinenting-tegen-hondsdolheid-naar-de-tropen afbe $6 \mathrm{~d} 4 \mathrm{~b} /$ ?refer rer=https://www.google.com/

30. Folkehelseinstituttet (FHI). Slutt på utleveringsrestriksjoner for rabiesvaksine. [End of rabies vaccine delivery restrictions], Oslo: $\mathrm{FHI} ; 27$ Nov 2019. Norwegian. Available from: https://www.helsebiblioteket.no/samfunnsmedisinog-folkehelse/helseradet/_attachment/265659? ts=16fa8a8a55d\&download=true

31. Agence nationale de sécurité du médicament et des produits de santé (ANSM). Imogam rage $150 \mathrm{UI} / \mathrm{ml}$, solution injectable - Tensions d'approvisionnement. [Imogam rage $150 \mathrm{UI} /$ ml, injectable vaccine - Supply tensions]. Saint-Denis: ANSM;8 Apr 2019. French. Available from: https://ansm. sante.fr/S-informer/Informations-de-securite-Ruptures-destock-des-medicaments/IMOGAM-RAGE-150-UI-ml-solutioninjectable-Tensions-d-approvisionnement

32. Institute of Tropical Medicine (ITM). Ajustement du traitement antirabique dû à une rupture de stock du vaccin. [Adjustment of the treatment against rabies due to a shortage in the vaccine stockpile]. Antwerp: ITM; 12 Jun 2019. French. Available from: https://www.itg.be/F/Article/ajustement-du-traitementantirabique-du-a-une-rupture-de-stock-du-vaccin

33. Mari E. Pénurie de vaccins contre la rage. [Shortage of rabies vaccines]. Paris: Le Parisien; 19 Jul 2018. French. Available from: https://www.leparisien.fr/societe/sante/penurie-devaccins-contre-la-rage-19-07-2018-7825983.php

34. Taylor E, Banyard AC, Bourhy H, Cliquet F, Ertl H, FehlnerGardiner C, et al. Avoiding preventable deaths: The scourge of counterfeit rabies vaccines. Vaccine. 2019;37(17):22857. https://doi.org/10.1016/j.vaccine.2019.03.037 PMID: 30922698

35. Food and Agriculture Organization of the United Nations, World Organisation for Animal Health, World Health Organization, Global Alliance for Rabies Control. Zero by 30: the global strategic plan to end human deaths from dog-mediated rabies by 2030. Geneva: WHO, 2018. Available from: https://apps. who.int/iris/bitstream/handle/10665/272756/9789241513838eng.pdf?ua $=1$

36. European Directorate for the Quality of Medicines and Healthcare. Guide to the quality and safety of organs for transplantation, 7th edition. Strasbourg: Council of Europe; 2018. Available from: https://www.edqm.eu/en/news/ new-release-7th-edition-guide-quality-and-safety-organstransplantation

37. European Directorate for the Quality of Medicines and Healthcare. Guide to the quality and safety of tissues and cells for human application, 4th edition. Strasbourg: Council of Europe; 2018. Available from: https://www.edqm.eu/en/ organs-tissues-and-cells-technical-guides

38. Rabies confirmed in an illegally imported dog in France. Vet Rec. 2015;176(22):558. https://doi.org/10.1136/vr.h2895 PMID: 26025705

39. Pérez de Diego AC, Vigo M, Monsalve J, Escudero A. The One Health approach for the management of an imported case of rabies in mainland Spain in 2013. Euro Surveill. 2015;20(6):21033. https://doi.org/10.2807/1560-7917. ES2015.20.6.21033 PMID: 25695478

40. Ministère de l'Agriculture et de l'Alimentation. Cas de rage importé détecté chez un chiot ramené du Maroc sur l'île de Ré. [Imported case if rabies in a puppy from Morocco on Ré island]. Paris: Ministère de l'Agriculture et de l'Alimentation. 15 Feb 2020. French. Available from: https://agriculture.gouv.fr/telech arger $/ 107839$ ?token $=f_{1}$ fb4beb809cb0918838431foec1f5a1

41. Schmiedel S, Panning M, Lohse A, Kreymann KG, Gerloff $C$, Burchard G, et al. Case report on fatal human rabies infection in Hamburg, Germany, March 2007. Euro Surveill. 2007;12(5):E0705315.

42. Rimhanen-Finne R, Järvinen A, Kuusi M, Quiambao BP, Malbas FF Jr, Huovilainen A, et al. Imported human rabies, the Philippines and Finland, 2007. Emerg Infect Dis. 2010;16(8):1318-9. https://doi.org/10.3201/eid1608.091380 PMID: 20678336

43. Hunter M, Johnson N, Hedderwick S, McCaughey C, Lowry $\mathrm{K}, \mathrm{McC}$ Conville J, et al. Immunovirological correlates in human rabies treated with therapeutic coma. J Med Virol. 2010;82(7):1255-65. https://doi.org/10.1002/jmv.21785 PMID: 20513093

44. Santos A, Cale E, Dacheux L, Bourhy H, Gouveia J, Vasconcelos P. Fatal case of imported human rabies in Amadora, Portugal, August 2011. Euro Surveill. 2012;17(12):20130. PMID: 22490309

45. Pathak S, Horton DL, Lucas S, Brown D, Quaderi S, Polhill S, et al. Diagnosis, management and post-mortem findings of a human case of rabies imported into the United Kingdom from India: a case report. Virol J. 2014;11(1):63. https://doi. org/10.1186/1743-422X-11-63 PMID: 24708671

46. Program for Monitoring Emerging Diseases (Pro-MED). Rabies - Netherlands ex Haiti, canine, human. Archive number: 2013;1791201(20130625):25. Available from: https:// promedmail.org/promed-post/?id=1791201

47. Program for Monitoring Emerging Diseases (Pro-MED). Rabies - Netherlands ex India: (Tamil Nadu) canine, human. Archive number: 2014;2721553(20140825):25. Available from: https:// promedmail.org/promed-post/?id $=2721553$

48. Contou D, Dacheux L, Bendib I, Jolivet S, Rodriguez C, Tomberli F, et al. Severe ketoalkalosis as initial presentation of imported human rabies in France. J Clin Microbiol. 2015;53(6):1979-82. https://doi.org/10.1128/JCM.00219-15 PMID: 25854482

49. Lourido M. Muere de rabia una mujer en Madrid. [A woman in Madrid dies from rabies]. Madrid: Cadena SER; 20 Jun 2014. Spanish. Available from: https://cadenaser.com/ ser/2014/06/20/sociedad/1403230405_850215.html

50. Hommel C. Cas de rage confirmé en France au retour du Sri Lanka. [One case of rabies in France in a travellers returning from Sri Lanka]. MesVaccins.net. [Accessed: 8 Jul 2020]. French. Available from: https://www.mesvaccins.net/web/ news/11418-cas-de-rage-confirme-en-france-au-retour-du-srilanka

51. Program for Monitoring Emerging Diseases (Pro-MED). Rabies, human - UK: (England) ex Morocco, ex feline. Archive number: 20181113.6142425.13 Nov 2018. Available from: https:// promedmail.org/promed-post/?id=6142425

52. European Centre for Disease Prevention and Control (ECDC). Communicable Disease Threat Report, week 50, 8-14 December, Rabies imported cases - EU/EEA - 2019. Stockholm: ECDC; 13 Dec 2019. Available from: https://www.ecdc.europa. eu/en/publications-data/communicable-disease-threatsreport-8-14-december-2019-week-50 
License, supplementary material and copyright

This is an open-access article distributed under the terms of the Creative Commons Attribution (CC BY 4.0) Licence. You may share and adapt the material, but must give appropriate credit to the source, provide a link to the licence and indicate if changes were made.

Any supplementary material referenced in the article can be found in the online version.

This article is copyright of the authors or their affiliated institutions, 2020. 